\title{
Psychophysiological, cognitive and behavioral aspects of malnutrition in Alzheimer's disease: a review
}

\author{
Juliana Sartori Bonini", Vanessa Fernanda Goes", Camilla Fagundes de Oliveira"**, \\ Andersom Ricardo Fréz ${ }^{*+* *}$, Carla Evelyn Coimbra Nuñez ${ }^{*+* * *}$, Pâmela Billig Mello-Carpes ${ }^{* *+* * *}$, \\ Weber Claudio Francisco Nunes da Silva ${ }^{* * * * * *}$
}

\begin{abstract}
Alzheimer's Disease is characterized by a progressive loss of cognitive and behavioral functions, also caused by changes to the neuroendocrine system and eating behaviors, and can lead to patient malnutrition and result in a nutritional imbalance with consequent malnutrition, affecting the overall health condition in patients, causing organic complications and influences in the evolution of dementia. The study objective present some information relating to the main factors involved in weight loss in AD patients reported in previous studies. As method use non-systematic review of the literature in the period 1988-2014, with search conducted in MEDLINE, LILACS and SciELO electronic library. Results 58 scientific articles reviewed and subdivided in categories for discussion, like cognitive losses, psychological symptoms, dysphagia and others. Conclude that
\end{abstract}

unfulfilled nutritional needs associated with increased energy demands and various alterations can lead to a rapid, undesirable, and sharp decline in nutritional status in patients with AD.

Keywords: Dementia. Nutritional Status. Weight Loss. Quality of life.

\section{Introduction}

Dementia is one of the most common health problems among the elderly and is also one of the leading causes of disability in this age group (PILOTTO et al., 2009). Alzheimer's disease (AD) is the most common type of dementia (THOMAS et al., 2008) responsible for over $50 \%$ of dementia cases in the elderly aged 65 years and older (HERRERA et

* Pharmacy Department - Pos-Graduate in Pharmaceutical Sciences and Neuroscience and Behavior Laborator. Central-Western State University. Mailing Adress: Rua Simeão Varelá de Sá, 03 - Vila Carli, CEP 85040-080, Guarapuava/PR/Brasil. E-mail: juliana.bonini@gmail.com

** $\quad$ Post-Graduate Program in Nutrition. Federal University of Santa Catarina. Email: goesfvanessa@gmail.com

**** Undergraduate in Physiotherapy - Departament of Physiotherapy. Central-Western State University E-mail: cahmi.lpb@gmail.com

***** Teacher in Departament of Physiotherapy. Central-Western State University. Email: Central-Western State University E-mail: andersom_frez@yahoo.com.br

***** Teacher in Departament of Nutrition. Central-Western State University. E-mail: carlanunez@gmail.com

******* Physiology Research Group - Teacher in Federal University of Pampa. E-mail: panmello@hotmail.com

******** Department of Pharmacy. Department of Pharmacy. E-mail: claudion@gmail.com

$\rightarrow$ http://dx.doi.org/10.5335/rbceh.2014.4432

Recebido em: 19/10/2014. Aceito em: 06/01/2015 
al., 2002). It is estimated that the prevalence of $\mathrm{AD}$ doubles every five years after this age reaching from $26 \%$ to $45 \%$ in patients over 85 years old (PILOTTO et al., 2009). Currently, more than 24 million people are affected worldwide and 4.6 million new cases are recorded per year making $\mathrm{AD}$ an important public health problem (IRVINE et al., 2008).

$\mathrm{AD}$ is a neurodegenerative disease characterized by the progressive loss of cognitive and behavioral functions (IRVINE et al., 2008) it progresses through an insidious installation and presents multifactorial etiology (HERRERA et al., 2002). Several studies indicate possible risk factors for dementia such as age, hypercholesterolemia, diabetes type 2 , hypertension, physical inactivity, smoking, obesity, ethnicity, gender, and genetic factors (KIVIPELTO et al., 2005; RUSANEN et al., 2011).

The pathophysiology of $\mathrm{AD}$ includes severe neuronal loss, impaired neurotransmission, and the emergence and proliferation of amyloid plaques (senile plaques) in the neuronal interstice of neurofibrillary tangles in the cytoplasm of neurons (THOMAS et al., 2008; WALDAU; SHETTY, 2013). These alterations lead to a decline in cognitive functions by causing a series of biochemical and structural changes in the brain.

Cognitive losses and neuropsychiatric changes arising from brain atrophy seem to contribute to weight loss and nutritional deficit in $\mathrm{AD}$ patients (GILLETTE-GUYONNET et al., 2000). Weight loss occurs in approximately $40 \%$ of $\mathrm{AD}$ patients. It can often precede the disease onset and even assist in the cli- nical diagnosis of the disease (GUÉRIN et al., 2005). However, the Body Mass Index (BMI) is mostly compromised at the most advanced stages of the disease. On the other hand, low BMI or low weight is associated with increased risk of developing AD (STEWART et al., 2005), and its severity and speed of progression (GILLETTE-GUYONNET et al., 2000; GRUNDMAN, 2005).

In the Alzheimer's Disease, the feeding habits are affected, and eating becomes increasingly difficult during the disease's evolution (STEENHAGEN; MOTTA, 2006). However, weight loss may arise not only from memory proble$\mathrm{ms}$, food refusal, and progressive difficulty related to food intake, but also from an increased energy demand associated with ambulation and unintended moves. Moreover, the presence of infections and consequent elevation of the basal metabolism can also contribute to weight loss (SPACCAVENTO et al., 2009).

The speed of weight loss can vary. It can be sharp with the dropping of several pounds in a short period of time, or moderate but steady according to the disease progression (GUÉRIN et al., 2005; SPACCAVENTO et al., 2009). According to Guérin et al. (2005), the weight loss kinetics in $\mathrm{AD}$ patients varies with the severity of the disease. These authors conducted a study with 395 patients and observed steady weight loss in most of the patients (about $33.4 \%$ ) and severe weight loss (greater than or equal to $5 \mathrm{~kg}$ in 6 months) in fewer patients (10.2\%). Sharp weight loss in a short period could result from acute diseases, hospitalization, institutionalization, and changes in living conditions. 
In the study by Spaccavento et al. (2009), AD patients presenting risk of malnutrition demonstrated greater cognitive impairment, greater difficulties in performing daily activities, and greater motor deficit when compared to patients with eutrophic nutritional status, which seems to have a protective effect on the development of $\mathrm{AD}$. Weight loss and consequent malnutrition causes a series of complications that lead to infections, respiratory failure, and heart failure, increasing disease severity and patient mortality (GUÉRIN et al., 2005).

Other serious complications related to malnutrition include reduced immune function, deficient wound healing, depression, apathy, compromised intestinal integrity, hypothermia, decreased hepatic protein synthesis, glomerular filtration, and production of gastric juice (SAUNDERS; SMITH; STROUD, 2011).

Before the changes related to malnutrition, cited above, we present some information on the main factors involved in weight loss in patients with $\mathrm{AD}$, as reported by previous studies.

\section{Materials and methods}

Considering high malnutrition rates in patients with Alzheimer's disease, both in Brazil and worldwide, the aim of this paper is to review the causes for this increase noted in the scientific literature. The study conducted through non-systematic review of literature in the period 1988-2014, resulted in 58 reviewed scientific articles. Inclusion criteria were the bibliographic search words such as Alzheimer's disease, loss of weight, agnosia, apraxia, memory loss, behavioral symptoms, dysphagia, leptin, neuroinflammation, seeking causal aspects of malnutrition in case to alert the public policies and health professionals. This study was conducted between the years 2011 to 2014 . The searches occurred in MEDLINE, LILACS and SciELO electronic library.

\section{Results}

After reviewing the 58 articles, subdivided into six items for discussion of malnutrition in patients with $\mathrm{AD}$.

\section{Cognitive losses}

Epidemiological studies indicate a complex relationship between the proportions of fat and lean mass and cognition in all ages (GUSTAFSON et al., 2003; WHITMER et al., 2005). According to Hsu-Ko et al. (2006), loss of lean mass is associated with worse cognitive performance in the elderly.

It has been observed that the BMI is lower among elderly individuals with dementia than in elderly without impaired cognition (GUSTAFSON et al., 2003; FAXÉN-IRVING; BASUN; CEDERHOLM, 2005). A positive association between cognitive dysfunction and reduced muscle mass in $\mathrm{AD}$ patients is generally identified as sarcopenia (NOURHASHÉMI et al., 2002). In these cases, a direct relationship between total brain volume and body composition is observed; brain atrophy is suggested to be directly related to the loss of lean mass observed in $\mathrm{AD}$ patients (BUCHMAN et al., 2006). 
As discussed by Muñoz, Agudelo e Lopera (2006), some of the characteristic symptoms present in $\mathrm{AD}$, such as agnosia and apraxia, can cause decreased food intake and, consequently, increased weight loss. Patients with agnosia might not recognize food and silverware, while patients with apraxia appear to have difficulties using silverware and/ or problems swallowing (SANDMAN; NORBERG, 1988).

Memory loss may affect the preparation of food and its consumption; patients can forget to eat, refuse food, or even repeat the same meal (SANDMAN; NORBERG, 1988; VELOSO, 2004). Memory loss can also affect the perception of basic needs such as thirst, hunger, and satiety, which can lead to the patient spending a whole day without ingesting food and water, and thus losing weight and becoming dehydrated (CALDAS, 2001).

Changes in the sense of smell also occur in $\mathrm{AD}$ patients, especially in the early stages of the disease, and may affect food consumption (GILBERT; BARR; MURPHY, 2004). Olfaction and other senses (vision and gustation) are necessary to initiate salivation and motion to start eating (FURKIM, 1999). These patients tend to prefer soft, moist, paste and liquid foods, and sometimes tend to increase the amount of salt and sugar in their diet due to changes in their tasting abilities (SILVA et al., 2008).

Executive dysfunction interferes in many aspects such as choosing food, feeling satisfied, and the duration of the meal (GILLIOZ et al., 2009). Speaking and understanding impairments also hinder feeding because patients might have difficulty in naming what they want to eat and understanding the meaning of words from those assisting them (ATHLIN et al., 1990)

The caregiver is often unable to identify the source of the aversion to food. In many cases, the bite reflex can be erroneously interpreted as a rejection to food. These circumstances make the patient increasingly dependent. Around 50\% of $\mathrm{AD}$ patients lose the ability to feed themselves within eight years of disease diagnosis (VOLICER et al., 1989).

\section{Psychiatric and behavioral disorders}

In $\mathrm{AD}$, the behavior changes are part of the clinical status and occurs in $90 \%$ of cases (GARCÍA-ALBERCA; MUÑOZ; TORRES, 2010). Among the most common disorders are depression and apathy; irritability; verbal and physical aggression; anxiety; disinhibition; repetitive behaviors; walk incessant; delusions; hallucinations; changes in sleep-wake cycle and eating patterns (BURNS; JACOBY; LEVY, 1990). However, the three groups of symptoms described most often are: depressive symptoms, agitation and psychotic symptoms (WEINER et al., 1996).

Behavioral disorders may predispose patients with $\mathrm{AD}$ to weight loss through at least two ways: (1) increased energy expenditure (eg, agitation, repetitive movements) and (2) reducing calorie intake (eg, distraction, agitation, depression) (WHITE et al., 2004).

Isolated depressive symptoms can be found in up to $87 \%$ of patients with 
$\mathrm{AD}$ at some stage in the disease, while major depression is less common appearance, around $24 \%$. One of the most common manifestations of depression is loss of appetite and weight (WESTIN et al., 1988; THOMPSON; MORRIS, 1991; MORLEY; KRAENZLE, 1994; BLAUM et al., 1995). Depression was associated with weight loss in $30 \%$ to $36 \%$ of outpatients or remain in nursing home (MORLEY; KRAENZLE, 1994). Thus, appetite changes due to depression may be another factor associated with malnutrition in those patients.

\section{Motor disorders - Dysphagia}

Swallowing depends on a complex sensorimotor mechanism controlled by the CNS, which includes voluntary and involuntary components. Previous studies showed that cognitive deficits found in neurological diseases, such as $\mathrm{AD}$, can cause an interruption in the present and necessary preparatory actions for swallowing (CORREIA et al., 2010).

This swallowing impairment may result in dysphagia, which is a common clinical manifestation in patients with dementia of the Alzheimer's type (28 to $32 \%$ ) (MUÑOZ; AGUDELO; LOPERA, 2006). Dysphagia may be present since the early stages of $\mathrm{AD}$ (CORREIA et al., 2010) and leads to nutritional and social consequences that impact the quality of life of the individual.

The main changes in swallowing found in these patients are lingual motor dysfunction, delay in firing the swallowing reflex, failure of the oral motor control of food mass, retention of food in the val- lecula and pyriform sinus, food penetration and aspiration, mainly for liquids, and absent mastication. Commonly, it is verified that masticatory movements become slower and uncoordinated, making swallowing difficult and causing nutritional disorders (CAMPOS et al., 2000).

Furthermore, dysphagia can lead to inadequate dietary intake driven by the consistency of foods. Some individuals change the consistency of preparations by adding large amounts of water to adapt the food to their symptoms; however, this reduces the total caloric value of the food and contributes to increased weight loss. The difficulty in swallowing thin liquids, including saliva, requires progressively greater coordination and control on the part of the $\mathrm{AD}$ patient, which increases the risk of aspiration pneumonia and recurrent respiratory tract infections (SMITH, 2006). The most severe phases of dysphagia are usually associated with aspiration pneumonia. Communication difficulties are also associated with dysphagia in many cases (SANDMAN; NORBERG, 1988).

\section{Endocrine alterations}

Nutrient intake and metabolism are influenced by the functioning of a set of neural structures and specific neurochemical and neuroendocrine systems. Leptin and insulin are the main energy signaling factors in the neuroendocrine control of energy metabolism. (HALLSCHMID et al., 2008). These two hormones act both peripherally and in the CNS where they interact as hypothalamic receptors (REAGAN, 2007). 
Leptin is a protein found in adipose tissue that acts as a hormone controlling food consumption through receptors found in the hypothalamus. This hormone is involved in control of body fat (storage and mobilization), reproductive and immune systems, bone homeostasis, insulin sensitivity, and neuronal activity. Leptin receptors have been identified in both peripheral tissues and neurons, including in the hippocampus which is particularly vulnerable to $\mathrm{AD}$ (HOLDEN et al., 2009).

In Borer (2014), it was shown that obesity induces hyperleptinemia suppressing insulin lipogenic action and inhibits bone mineral ability, suggesting that leptin has important factors with regard to maintenance of skeletal stability lean mass and even body's own fat.

Reduced leptin levels are positively associated the risk of $\mathrm{AD}$, but not the severity of the dementia. A large-scale prospective study that followed about 3.000 elders for approximately four years demonstrated that participants with low leptin levels showed a greater cognitive decline compared to individuals with higher levels of leptin (HOLDEN et al., 2009).

Insulin exerts metabolic, neurotrophic, neuromodulatory, and neuroendocrine functions in the brain and participates in synaptic plasticity. Several studies in humans identified insulin receptors in brain regions such as in the olfactory bulb, hypothalamus, hippocampus, and cerebellum. Insulin also regulates hypothalamic participation in food intake, smell in the olfactory bulb, and body weight control (PLIQUETT et al., 2006). The effect of hyperglycemia and insulin resistance on the hippo- campus has been demonstrated to lead to losses in hippocampal plasticity and cognition impairment (REAGAN, 2007). In addition, hyperglycemia can be a contributing factor to the incidence of $\mathrm{AD}$ (RAFFAITIN et al., 2009).

Decreased food intake in $\mathrm{AD}$ patients can also result from decreased orexigenic peptides such as the neuropeptide $\mathrm{Y}$ and norepinephrine. Other hormones such as ghrelin, orexin, cholecystokinin, and oxyntomodulin combine with other signals to control food intake by acting on hypothalamic centers (REAGAN, 2007).

Thus, the interconnected operation between neural, physiological, endocrine, and behavioral responses participates in the control of food intake and is involved in the ontogeny of weight loss (LANDEIRO; QUARANTINI, 2011).

\section{Inflammatory activity}

Neuroinflammation, mainly triggered by the deposition of proteins such as the $\beta$-amyloid peptide, is observed in AD patients (DENG et al., 2006). The hyperactivation of microglia cells and astrocytes produces a high amount of inflammatory cytokines such as the Tumor Necrosis Factor (TNF), interleukins, and interferon, which lead to chronic inflammatory responses especially in the neocortex, hippocampus, and cerebellum. This chronic inflammation predisposes the development of $\mathrm{AD}$ through an increased accumulation of $\beta$-amyloid (BLASKO et al., 1999).

Studies show that patients with $\mathrm{AD}$ exhibit elevated levels of TNF- $\alpha$ and interleukin- 6 in the brain, in the cerebrospinal fluid (CSF) and blood (TAR- 
KOWSKI et al., 1999; SWARDFAGER et al., 2010).

The presence of $\beta$-amyloid in the CNS, increasing local inflammatory response leading to the formation of pro-inflammatory cytokines (TNF and IL-6), these cytokines that increase the enzymatic process of APP and therefore to increased production of $\beta$-amyloid, which is known as cytokine cycle (BIESSELS; KAPPELLE, 2005; WATSON; CRAFT, 2006).

Some studies showed also that interleukin 4 and interleukin 10 serum concentrations were higher in patients with lower caloric intake. This finding deserves consideration because this promoted humoral mediated immunity (CATAPANO et al., 2008).

Moreover, the causes of weight loss in this patients are multifaceted and include loss of appetite secondary to deterioration of brain regions (SMITH; GREENWOOD, 2008). This loss of appetite, in the Carrero et al. (2007) study, was associated with increased inflammation, or higher concentrations in interleukin serum and poor nutritional status (lower serum concentrations of insulin-like growth factor).

\section{Alterations in energy needs}

An important factor that can lead to weight loss is the increase in energy needs in $\mathrm{AD}$ patients due to some exacerbated psychomotor agitation (MUÑOZ; AGUDELO; LOPERA, 2006).

$\mathrm{AD}$ patients can also exacerbate their energy loss through infectious processes that lead to elevated basal metabolism. $\mathrm{AD}$ also affects organic needs of protein and calories, because the changes in the dynamics of deglutition, causing losses in nutritional aspects of hydration and metabolism of patients (STEENHAGEN; MOTTA, 2006).

The deregulation of the energetic metabolism and food intake is also observed in AD patients due to CNS impairment. The brain atrophy observed in $\mathrm{AD}$ can unbalance the patient's appetite and metabolic processes involved in body weight control (MUÑOZ et al., 2006).

Therefore, it is suggested that low food intake coupled with increased energy needs cause a nutritional unbalance that triggers substantial weight loss leading patients to a stage of malnutrition (REAGAN, 2007; POEHLMAN; DVORAK, 2000; WHITE et al., 2004).

\section{Final considerations}

The inability to feed itself is a determining factor for the diagnosis of dementia according to the National Institute of Neurological and Communicative Disorders and Stroke and the Alzheimer's Disease and Related Disorders Association (NINCDS-ADRDA) (DUBOIS et al., 2007). In this way, the food supplement becomes an important strategy for maintaining the nutritional and cognitive state of patients. The Souvenaid ${ }^{\circledR}$ formulation (Nutricia NV, Zoetermeer, Holanda), which contains nutrients were combined in order to contribute to the formation and functioning synapses in $\mathrm{AD}$ patients, as having positive results compared to other nutritional formulations (WILDE et al., 2011).

This food supplement is composed of fatty acids docosahexaenoic acid (DHA) and eicosapentaenoic acid (EPA), uridine 
monophosphate (UMP), choline, phospholipids, folic acid, vitamins B6, B12, C, E and selenium, which are forming precursors neuronal membranes. Preclinical studies have shown increased phospholipid synthesis, dendritic growth and synaptic proteins (CANSEV et al., 2014) and clinical studies have shown that Souvenaid ${ }^{\circledR}$ preserves the memory and to maintain the functional organization of the brain when evaluated by electroencephalogram in patients with $\mathrm{AD}$ (WAAL et al., 2014).

\section{Conclusion}

Before our findings in the literature, the conclusion refers to the results already referenced. Unfulfilled nutritional needs associated with increased energy demands and alterations that are physiologic, cognitive, psychological, behavioral, endocrine, and inflammatory can lead to a rapid, undesirable, and sharp decline in nutritional status in patients with $\mathrm{AD}$ diagnosis. Malnutrition can affect the development of dementia and $\mathrm{AD}$ affects food intake and nutritional balance due to cognitive and motor disorders. Malnutrition in $\mathrm{AD}$ patients results in serious impairments in their general health and well-being that can lead to increase morbidity and mortality. Moreover, the nutritional status appears to be a good indicator of quality of life in these patients.

\section{Aspectos psicofisiológicos, cognitivos e comportamentais da desnutrição na doença de Alzheimer: revisão de literatura}

\section{Resumo}

A doença de Alzheimer (DA) é caracterizada por uma perda progressiva das funções cognitivas e comportamentais, causadas por alterações no sistema neuroendócrino e nos comportamentos alimentares que podem levar à desnutrição do paciente e resultar em um desequilíbrio nutricional, afetando o estado geral de saúde dos pacientes, provocando complicações orgânicas e influências na evolução da demência. Este estudo objetiva apresentar algumas informações relativas aos principais fatores envolvidos na perda de peso em pacientes com DA relatados em estudos anteriores. Como método, utiliza-se uma revisão não sistemática da literatura, no período 19882014, com pesquisa realizada no Medline, Lilacs e na biblioteca eletrônica SciELO. Essa pesquisa resulta de 58 artigos científicos que foram revisados e subdivididos em categorias para discussão, como as perdas cognitivas, os sintomas psicológicos, a disfagia, e outros aspectos. Conclui-se que não cumpridas as necessidades nutricionais associadas com aumento da demanda de energia, várias alterações podem levar a um declínio rápido, indesejável e nítido no estado nutricional em pacientes com DA.

Palavras-chave: Demência. Estado Nutricional. Perda de peso. Qualidade de vida.

\section{Conflict of interests}

The author(s) declare(s) that there is no conflict of interests regarding the publication of this article.

This manuscript was reviewed by a professional science editor and a native English-speaking editor to improve readability. 


\section{References}

ATHLIN, E.; NORBERG, A.; ASPLUND, K. Caregivers' perceptions and interpretations of severly demented patients during feeding in a task assignment system. Scandinavian Journal of Caring Sciences, Stockholm-SE, v. 4, n. 4, p. 147-155, 1990.

BIESSELS, G. J.; KAPPELLE, L. J. Increased risk of Alzheimer's disease in Type II diabetes: insulin resistance of the brain or insulin-induced amyloid pathology?. Biochemical Society Transactions, London-UK, v. 33, n. 5, p. 1041-1044, Nov. 2005.

BLASKO, I. et al. TNF. A plus IFN g induce the production of Alzheimer b - amyloid peptides and decrease the secretion of APPs acerbate the fundamental pathology in $\mathrm{AD}$. The Faseb Journal, Bethesda-US, v. 13, n. 1, p. 63-68, Jan. 1999.

BLAUM, C. S.; FRIES, B. E.; FIATARONE, M. A. Factors Associated With Low Body Mass Index and Weight Loss in Nursing Home Residents. Journal of Gerontology, Washington-US, v. 50, n. 3, p. 162-168, May 1995.

BORER, K. T. Counterregulation of insulin by leptin as key component of autonomic regulation of body weight. World journal of diabetes, Pleasanton-US, v. 5, n. 5, p. 606629, Oct. 2014.

BUCHMAN, A. S. et al. Body mass index in older persons is associated with Alzheimer. Neurology, New York-US, v. 67, p. 1.9491.954, Dec. 2006.

BURNS, A.; JACOBY, R.; LEVY, R. Psychiatric Phenomena in Alzheimer's Disease. II: Disorders of Perception. British Journal of Psychiatry, London-UK, v. 157, p. 76-81, July 1990.

Caldas C. P. Cuidando de uma pessoa idosa que vivencia um processo de demência numa perspectiva existencial. In: GUERREIRO T; CALDAS C. P. Memória e Demência: (re) conhecimento e cuidado. Rio de Janeiro: UERJ/ UnATI; 2001. p. 129-206.
CAMPOS, M. T. F. de S.; MONTEIRO, J. B. R.; ORNELAS, A. P. R. de C. Fatores que afetam o consumo alimentar e a nutrição do idoso. Revista de Nutrição, Campinas, v. 13, n. 3, p. 157-165, set./dez. 2000.

CANSEV, M. et al. A specific multi-nutrient enriched diet enhances hippocampal cholinergic transmission in aged rats. Neurobiology of Aging, New York - US, v. 36, p. 344-351, July 2014.

CARRERO, J. J. et al. Comparison of nutritional and inflammatory markers in dialysis patients with reduced appetite. The American Journal of Clinical Nutrition, Bethesda-US, v. 85, p. 695-701, Mar. 2007.

CATAPANO, G. et al. Nutrient intake and serum cytokine pattern in elderly people with heart failure. European Journal of Heart Failure, New York-US, v. 10, p. 428434, Apr. 2008.

CORREIA, S. D. M. et al. Swallowing in moderate and severe phases of Alzheimer's disease. Arquivo de Neuropsiquiatria, São Paulo, v. 68, n. 6, p. 855-861, Dec. 2010.

DENG, X. H. et al. Cytokine-induced activation of glial cells in the mouse brain is enhanced at an advanced age. Neuroscience, Oxford-UK, v. 141, n. 2, p. 645-661, Aug. 2006.

DUBOIS, B. et al. Research criteria for the diagnosis of Alzheimer's disease: revising the NINCDS-ADRDA criteria. Lancet Neurology, London-UK, v. 6, n. 8, p. 734-746, Aug. 2007.

FAXÉN-IRVING, G.; BASUN, H.; CEDERHOLM, T. Nutritional and cognitive relationships and long-term mortality in patients with various dementia disorders. Age and ageing, London-UK, v. 34, n. 2, p. 136-141, Mar. 2005.

FURKIM, A; SANTINI, C.S. Disfagias Orofaríngeas, p. 26. São Paulo: Pró fono, 1999.

GARCÍA-ALBERCA, J. M.; MUÑOZ, P. L.; TORRES, M. B. Neuropsychiatric and behavioral symptomatology in Alzheimer disease. Actas Españolas de Psiquiatría, Madrid-ES, v. 38, n. 4, p. 212-222, July/Aug. 2010. 
GILBERT, P. E.; BARR, P. J.; MURPHY, C. Differences in olfactory and visual memory in patients with pathologically confirmed Alzheimer's disease and the Lewy body variant of Alzheimer's disease. Journal of the International Neuropsychological Society, Cambridge-UK, v. 10, p. 835-842, Oct. 2004.

GILLETTE-GUYONNET, S. et al. Weight loss in Alzheimer disease. The American Journal of Clinical Nutrition, Bethesda-US, v. 71 , p. $637 \mathrm{~S}-642 \mathrm{~S}, 2000$.

GILLIOZ, A.-S. et al. Spared and Impaired Abilities in Community-Dwelling Patients Entering the Severe Stage of Alzheimer's Disease. Dementia and geriatric cognitive disorders, Basel-CH, v. 28, p. 427-432, Nov. 2009.

GRUNDMAN, M. Weight loss in the elderly may be a sign of impending dementia. Archives of neurology, Chicago-US, v. 62, n. 1, p. 20-22, Jan. 2005.

GUÉRIN, O. et al. Different modes of weight loss in Alzheimer disease : a prospective. The American Journal of Clinical Nutrition, Bethesda-US, v. 82, n. 3, p. 435-441, Aug. 2005.

GUSTAFSON, D. et al. An 18-Year Follow-up of Overweight and Risk of Alzheimer Disease. Archives of Gerontology and Geriatrics, Amsterdam-NL, v. 163, p. 1.524-1.528, July 2003.

HALLSCHMID, M. et al. Obese men respond to cognitive but not to catabolic brain insulin signaling. International Journal of Obesity, London-UK, v. 32, p. 275-282, Feb. 2008.

HERRERA, E. et al. Epidemiologic Survey of Dementia in a Community-Dwelling Brazilian Population. Alzheimer Disease and Associated Disorders, Hagerstown-US, v. 16, n. 2, p. 103-108, 2002.

HOLDEN, K. F. et al. Serum leptin level and cognition in the elderly: Findings from the Health ABC Study. Neurobiology of Aging, New York-US, v. 30, p. 1.483-1.489, Sept. 2009.
HSU-KO, K. et al. Cognitive Function in Normal-Weight, Overweight, and Obese Older Adults: An Analysis of the Advanced Cognitive Training for Independent and Vital Elderly Cohort. Journal American of Geriatric, New York-US, v. 54, n. 1, p. 97-103, Jan. 2006.

IRVINE, G. B. et al. Protein Aggregation in the Brain: The Molecular Basis for Alzheimer's and Parkinson's Diseases. Molecular Medicine, New York-US, v. 14, n. 7-8, p. 451-464, July/Aug. 2008.

KIVIPELTO, M. et al. Obesity and Vascular Risk Factors at Midlife and the Risk of Dementia and Alzheimer Disease. Archives of neurology, Chicago-US, v. 62, p. 1.556-1.560, Oct. 2005.

LANDEIRO, F. M.; QUARANTINI, L. D. C. Obesidade: Controle Neural e Hormonal do Comportamento Alimentar. Revista de Ciências Médicas e Biológicas, Salvador, v. 10, n. 3, p. 236-245, 2011.

MORLEY, J. E.; KRAENZLE, D. Causes of weight loss in a community nursing home. Journal of the American Geriatrics Society, New York - US, v. 42, n. 6, p. 583-585, June 1994.

MUÑOZ, A. M.; AGUDELO, G. M.; LOPERA, F. J. Diagnóstico del estado nutricional de los pacientes con demencia tipo Alzheimer registrados en el Grupo de Neurociencias, Medellín. Biomédica, Bogota-CO, v. 26, p. 113-125, 2006.

NOURHASHÉMI, F. et al. Is There a Relationship Between Fat-Free Soft Tissue Mass and Low Cognitive Function? Results From a Study of 7,105 Women. Journal of the American Geriatrics Society, New York-US, v. 50, n. 11, p. 1.796-1.801, Nov. 2002.

PILOTTO, A. et al. The Multidimensional Prognostic Index (MPI), Based on a Comprehensive Geriatric Assessment, Predicts Short- and Long- Term Mortality in Hospitalized Older Patients with Dementia. Journal Alzheimers Disease, Amsterdam-NL, v. 18, n. 1, p. 191-199, 2009. 
PLIQUETT, R. U. et al. The Effects of Insulin on the Central Nervous System - Focus on Appetite Regulation. Hormone and metabolic Research, Stuttgart-DE, v. 38, p. 442-446, July 2006.

POEHLMAN, E. T.; DVORAK, R. V. Energy expenditure, energy intake, and weight loss in Alzheimer. The American Journal of Clinical Nutrition, Bethesda-US, v. 71, p. 650-655, Feb. 2000.

RAFFAITIN, C. et al. Metabolic Syndrome and Risk for Incident Alzheimer's Disease or Vascular Dementia: The Three-City study. Diabetes Care, Alexandria-US, v. 32, n. 1, p. 169-174, Jan. 2009.

REAGAN, L. P. Insulin signaling effects on memory and mood. Current Opinion in Pharmacology, Oxford-US, v. 7, p. 633-637, Dec. 2007.

RUSANEN, M. et al. Heavy smoking in midlife and long-term risk of Alzheimer disease and vascular dementia. Archives of internal medicine, Chicago-US, v. 171, n. 4, p. 333-339, Feb. 2011.

SANDMAN, P. O.; NORBERG, A. Verbal communication and behaviour during meals in five institutionalized patients with Alzheimer-type dementia. Journal of Advanced Nursing, Oxford-US, v. 13, p. 571-578, Sept. 1988.

SAUNDERS, J.; SMITH, T.; STROUD, M. Malnutrition and undernutrition. Medicine, Abingdon-UK, v. 39, n. 1, p. 45-50, Jan. 2011.

SILVA, L. B. C. et al. Nutrition and dysphagia: body mass index, food consistency and food intake. Revista Brasileira de Nutrição Clínica, Porto Alegre, v. 23, n. 2, p. 91-96, 2008.

SMITH, K. L.; GREENWOOD, C. E. Weight loss and nutritional considerations in Alzheimer Disease. Journal of Nutrition for the Elderly, New York-US, v. 27, n. 3-4, p. 381-403, 2008.
SMITH, P. A. Nutrition, Hydration, and Dysphagia in Long-Term Care: Differing Opinions on the Effects of Aspiration. Journal of the American Medical Directors Association, Hagerstown-US, v. 7, n. 9, p. 545-549, Nov. 2006.

SPACCAVENTO, S. et al. Influence of nutritional status on cognitive, functional and neuropsychiatric deficits in Alzheimer's disease. Archives of Gerontology and Geriatrics, Amsterdam-NL, v. 48, p. 356-360, May/ June 2009.

STEENHAGEN, C. H. V. A.; MOTTA, L. B. Deglutition and aging: focus on facilitating and postural maneuvers utilized in rehabilitation for dysphagic patients. Revista Brasileira de Geriatria e Gerontologia, v. 9, n. 3, p. 89-100, 2006. Disponível em: <http:// revista.unati.uerj.br/scielo.php?script $=$ sci arttext\&pid=S1809-98232006000300007\&ln $\mathrm{g}=\mathrm{pt \& nrm=iso}>$. Acesso em: 4 Oct. 2014.

STEWART, R. et al. A 32-Year Prospective Study of Change in Body Weight and Incident Dementia. Archives of neurology, Chicago-US, v. 62, p. 55-60, Jan. 2005.

SWARDFAGER, W. et al. A meta-analysis of cytokines in Alzheimer's disease. Biological psychiatry, New York-US, v. 68, p. 930-941, Nov. 2010.

TARKOWSKI, E. et al. Intracerebral Production of Tumor Necrosis Factor-A, a Local Neuroprotective Agent, in Alzheimer Disease and Vascular Dementia. Journal of Clinical Immunology, New York-US, v. 19, n. 4, p. 223-230, July 1999.

THOMAS, A. V. et al. Visualizing Interaction of Proteins relevant to Alzheimer's Disease in intact Cells. Methods, Orlando-US, v. 44, n. 4, p. 299-303, Apr. 2008.

THOMPSON, M. P.; MORRIS, L. K. Unexplained weight loss in the ambulatory elderly. Journal of the American Geriatrics Society, v. 39, n. 5, p. 497-500, May 1991. 
VELOSO, P. Melhorar o estado nutricional dos doentes de Alzheimer. Nutrícias, Porto-PT, n. 4, p. 60-61, 2004.

VOLICER, L.; SELZER, B.; RHEAUME, Y. Progression of Alzheimer's disease. Journal of the American Dietic Association, Chicago-US, v. 89, n. 1, p.392-396, 1989.

WAAL, H. de. et al. The Effect of Souvenaid on Functional Brain Network Organisation in Patients with Mild Alzheimer's Disease: A Randomised Controlled Study. Plos One, San Francisco-US, v. 9, n. 1, p. 1-11, Jan. 2014.

WALDAU, B.; SHETTY, A. K. Behavior of neural stem cells in the Alzheimer brain. Cell Mol Life Sci, Basel-CH, v. 65, n. 15, p. 2.372-2.384, 2013.

WATSON, G. S.; CRAFT, S. Insulin resistance, inflammation, and cognition in Alzheimer's Disease: Lessons for multiple sclerosis. Journal of the Neurological Sciences, Amsterdam-NL, v. 245, p. 21-33, June 2006.

WEINER, M. F. et al. Measures of psyquiatric symptoms in Alzheimer patients: a review. Alzheimer Disease and Associated Disorders, Hagerstown - US, v. 10, n. 1, p. 20-30, 1996.

WESTIN, T. et al. Mental depression is associated with malnutrition in patients with head and neck cancer. Archives of Otolaryngology Head and Neck Surgery, Chicago-US, v. 114, n. 12 , p. 1.449-1.453, Dec. 1988.

WHITE, H. K. et al. 6-Month Observational Study of the Relationship Between Weight Loss and Behavioral Symptoms in Institutionalized Alzheimer's Disease Subjects. Journal of the American Medical Directors Association, Hagerstown-US, v. 5, n. 2, p. 89-97, Mar./Apr. 2004.

WHITMER, R. A. et al. Obesity in middle age and future risk of dementia: a 27 year longitudinal population based study. BMJ, London-UK, v. 330, n. 7.504, p. 1.360, Jun. 2005.
WILDE, M. C. de. et al. Utility of imaging for nutritional intervention studies in Alzheimer's disease. European Journal of Pharmacology, Amsterdam-NL, v. 668, p. 59-69, Sept. 2011. 